\title{
modern blackness
}

A book in the series

LATIN AMERICA OTHERWISE:

LANGUAGES, EMPIRES, NATIONS

Series editors:

Walter D. Mignolo, Duke University

Irene Silverblatt, Duke University

Sonia Saldívar-Hull, University of

California at Los Angeles 

Deborah A. Thomas

\section{MODERN BLACKNESS}

Nationalism, Globalization, and

the Politics of Culture

in Jamaica

o:

Duke University Press Durham \& London 2004 


\section{(C) 2004 Duke University Press}

All rights reserved

Printed in the United States of America on acid-free paper $\infty$

Designed by C. H. Westmoreland

Typeset in Quadraat by Keystone Typesetting, Inc.

Library of Congress Cataloging-in-Publication Data

Thomas, Deborah A., I966-

Modern blackness : nationalism, globalization and the politics of culture in Jamaica / Deborah A. Thomas.

p. cm. - (Latin America otherwise)

Includes bibliographical references and index.

IS BN 0-8223-3408-9 (cloth : alk. paper)

IS BN 0-8223-34I9-4 (pbk. : alk. paper)

I. Jamaica-Cultural policy. 2. Ethnicity-Jamaica. 3. Identity (Psychology)-Jamaica. 4. Nationalism-Jamaica. 5. Politics and culture-Jamaica-History. 6. Social classes-Jamaica. 7. Popular culture-Jamaica. 8. Globalization-Social aspects-Jamaica.

I. Title. II. Series.

FI874.T46 2004

972.92-dc22 2004012453 
Latin America Otherwise: Languages, Empires, Nations is a critical series. It aims to explore the emergence and consequences of concepts used to define "Latin America" while at the same time exploring the broad interplay of political, economic, and cultural practices that have shaped Latin American worlds. Latin America, at the crossroads of competing imperial designs and local responses, has been construed as a geocultural and geopolitical entity since the nineteenth century. This series provides a starting point to redefine Latin America as a configuration of political, linguistic, cultural, and economic intersections that demands a continuous reappraisal of the role of the Americas in history, and of the ongoing process of globalization and the relocation of people and cultures that have characterized Latin America's experience. Latin America Otherwise: Languages, Empires, Nations is a forum that confronts established geocultural constructions, that rethinks area studies and disciplinary boundaries, that assesses convictions of the academy and of public policy, and that, correspondingly, demands that the practices through which we produce knowledge and understanding about and from Latin America be subject to rigorous and critical scrutiny.

Modern Blackness is a history and ethnography of the cultural politics of nationalism in Jamaica. Starting with the years after independence, Thomas presents the changing valence of nationalist ideologies-from the awakenings of "the people" as a creole nation to today's nation, rooted in an ethos of urban "blackness." Thomas places nationalism in several contexts: from the history of Jamaica in a changing world, to the history of Mango Mount in a changing Jamaica. With great analytical sophistication, Thomas gives, then, a threedimensional view of the dynamics linking global forces, the Jamaican nation, and local possibilities: and all this with attention to political, economic, and cultural factors.

Modern Blackness is an ambitious book that manages to tell a big story of national and global transformations without sacrificing what matters-the dayto-day lives of "ordinary" Jamaicans. Thomas's generous vision, then, is a lesson in how to see otherwise: to appreciate the simultaneous workings of global, national, and local forces, without forgetting the human beings that constitute them; to understand that "culture" (like dance) is part of this dynamic; and to remember that the Caribbean, including the English-speaking Caribbean, and "Latin" America are part of each others' being in the history of the modern/ colonial world. 

for my family and my posse 
